\title{
Novel endoscopic approaches in the diagnosis and management of biliary strictures
}

\author{
Margaret G. Keane ${ }^{1}$, Neale J. Marlow ${ }^{2}$ and Stephen P. Pereira ${ }^{1 *}$
}

Addresses: ${ }^{1}$ UCL Institute for Liver and Digestive Health and ${ }^{2}$ UCL Medical School, University College London, London, UK

*Corresponding author: Stephen P. Pereira (stephen.pereira@ucl.ac.uk)

Fl000Prime Reports 2013, 5:38 (doi:10.12703/P5-38)

This is an open-access article distributed under the terms of the Creative Commons Attribution-Non Commercial License (http://creativecommons.org/licenses/by-nc/3.0/legalcode), which permits unrestricted use, distribution, and reproduction in any medium, provided the original work is properly cited. You may not use this work for commercial purposes.

The electronic version of this article is the complete one and can be found at: http://fl000.com/prime/reports/m/5/38

\begin{abstract}
Indeterminate bilary strictures present the clinician with a wide differential diagnosis. Histological confirmation is usually required for treatment, but tissue acquisition remains challenging. Novel developments in endoscopic technology, such as single operator cholangioscopy and confocal endomicroscopy, have led to improvements in diagnostic accuracy in recent years. In patients with non-resectable malignant biliary obstruction, effective biliary decompression improves symptoms and enables patients to undergo palliative therapies. Improvements in endoscopic techniques, biliary stents and the development of local ablative techniques have led to further improvements in stent patency and survival in these patients. In this article, we review emerging diagnostic and therapeutic techniques for the endoscopic management of indeterminate biliary strictures.
\end{abstract}

\section{Introduction}

Despite improved diagnostic techniques, strictures of the biliary tree (abnormal narrowing of the biliary duct, which drains bile) remain a diagnostic challenge. Competing diagnoses, which share initial clinical and radiological findings, include cholangiocarcinoma, primary sclerosing cholangitis and autoimmune cholangiopathy. This presents the clinician with a wide differential (Table 1) for the underlying cause of a biliary stricture, which is usually difficult to differentiate on imaging alone [1-3]. Due to the different management algorithms and outlook, it is essential that these conditions be diagnosed swiftly and accurately in order to guide appropriate therapy and optimise outcomes for patients.

Because of the difficulties sometimes encountered in establishing a diagnosis, definitive treatment may be delayed (e.g. surgery or palliative chemotherapy) or occasionally incorrectly given: for example, $8-25 \%$ of patients who undergo surgical resection for suspected cholangiocarcinoma will ultimately be found to have benign disease $[4,5]$. Many of these patients have an autoimmune cholangiopathy that can be effectively treated with steroids and other medical therapies [6-8].

Carbohydrate antigen (CA) 19-9 is the most widely used tumour marker of pancreaticobiliary malignancy, but its sensitivity and specificity are low and its role in clinical practice remains uncertain. The discovery and validation of new biomarkers for pancreaticobiliary malignancy remains an active field of research. A summary table of some of the biomarkers currently being investigated for the diagnosis of cholangiocarcinoma has been included for reference (Table 2).

Pancreaticobiliary malignancy is often diagnosed late and at an advanced stage when very few patients are eligible for curative surgical resection. However, in nonsurgical patients, effective biliary decompression improves symptoms. This review will provide an overview of the latest innovations in endoscopic techniques for the diagnosis and management of indeterminate biliary strictures. 
Table I. Differential diagnosis of indeterminate biliary stricture

\begin{tabular}{ll}
\hline Benign & Post-operative (following laparoscopic cholecystectomy or \\
& biliary anastomosis) \\
& Chronic pancreatitis \\
& Primary sclerosing cholangitis \\
& Autoimmune cholangiopathy, IgG4-related disease \\
& Post-radiation therapy \\
& Infections (TB, histoplasmosis, viral, parasitic, HIV \\
& cholangiopathy) \\
& Choledocholithiasis/Mirrizzi syndrome \\
& Vasculitis \\
& Trauma \\
& Ischaemia \\
& Sphincter of Oddi dysfunction \\
& Post biliary sphincterotomy \\
& Extraluminal compression (lymph nodes, vascular) \\
Cholangiocarcinoma & Pancreatic cancer \\
\end{tabular}

Table 2. Summary table of biomarkers for cholangiocarcinoma currently being evaluated

\begin{tabular}{lcc}
\hline Biomarkers (Serum) & Sensitivity (\%) & Specificity (\%) \\
\hline CA I9-9 (>I00 U/ml) [57-6I] & $60-89$ & $80-97$ \\
TTR (transthyretin)+CA I9-9 [62] & 98 & 100 \\
CEA (>22 micog/L) [63] & 68 & 82 \\
IL-6 (>25 pg/ml) [64] & 73 & 92 \\
MUCIN-5AC [65] & 88 & 90 \\
CYFRA 2I-I (>I.5 ng/mL) [66] & 56 & 88 \\
Matrix metalloproteinase-7 & 75 & 78 \\
(MMP 7) (>5.5ng/ml) [60] & 84 & 90 \\
M2-PK [6I] & & \\
Biomarkers (Bile) & & \\
CA 19-9 [67]. CEA [67], Ca I25 [67], fibronectin [68], Pancreatic elastase/ \\
amylase ratio [69], Mcm5 [70], Mac-2BP [7I], SSP4I I [72], Insulin-like growth \\
factor I [73], neutrophil gelatinase-associated lipocalin [74]. \\
\hline
\end{tabular}

\section{Diagnostics}

Standard endoscopic retrograde cholangiopancreatography with biliary brushings and intraluminal biopsy

Endoscopic retrograde cholangiopancreatography (ERCP) is typically undertaken following cross-sectional imaging, to enable tissue to be obtained for cytological or histological assessment. Standard ERCP and brush cytology have a variable sensitivity for malignancy of 9-57\% [9-12] and new techniques with improved diagnostic accuracy would be welcome.

Cholangiocarcinoma has been associated with mutations in several oncogenes and up to $80 \%$ of tumour cells have been shown to exhibit chromosomal aneuploidy [13]. Fluorescence in situ hybridization (FISH) and digital image analysis can therefore be used to assess for the presence of these DNA abnormalities in brush cytology. They have been shown to improve the overall sensitivity for detecting cholangiocarcinoma and in primary sclerosing cholangitis, where confirmation of cholangiocarcinoma is particularly challenging, presence of polysomy is highly suggestive of cholangiocarcinoma $[14,15]$. To date, their routine use in clinical practice has only been adopted by a few centres.

\section{Diagnostic endoscopic ultrasonography}

If ERCP findings are inconclusive, endoscopic ultrasonography with fine-needle aspiration (EUS-FNA) provides an alternative method for visualising and sampling the extrahepatic biliary tree, hilar masses, gallbladder and peri-hilar lymph nodes and vessels. A recent single-centre study found the technique to have a sensitivity for diagnosing cholangiocarcinoma of $73 \%$; sensitivity was significantly better in distal compared to proximal tumours (81\% vs. 59\%, respectively) [16]. In preoperative staging, EUS-FNA has been shown to locally stage cholangiocarcinoma more accurately than standard cross-sectional imaging. Following EUS-FNA, an additional $15-20 \%$ of patients are found to have locally advanced disease that is not amenable to surgical resection. However, concerns remain around the possibility of tumour seeding $[17,18]$. Some studies have combined EUS with novel techniques such as transient elastography when assessing pancreatic lesions and lymph nodes to improve the diagnostic accuracy of the technique [19].

Small studies have explored the efficacy of intraductal ultrasound in the pre-operative staging of cholangiocarcinoma. Initial studies have shown it to have a diagnostic accuracy of up to $90 \%$ and to have a particular role for detecting periductal tumour extension and portal vein invasion [20].

\section{Peroral cholangioscopy}

Peroral cholangioscopy and visually targeted biopsies are known to have a greater diagnostic accuracy than standard ERCP [21]. Recent improvements in cholangioscopes have led to a re-emergence of this technology. A single operator cholangioscopy system (Spyglass, Boston Scientific Corp, Natick, Massachusetts, USA) was introduced in 2006, which produces a 6000-pixel fibre optic image and enables visually directed intrabiliary biopsies via small disposable forceps (Figure 1). A multicentre study of single operator cholangioscopy, which included 140 patients with 'indeterminate' biliary strictures of unclear aetiology, found that sufficient material for histological examination was obtained in $88 \%$ and a definitive diagnosis was achieved in $85 \%$. The specificity and sensitivity for visually directed biopsies was $98 \%$ and 49\%, respectively. Higher sensitivities were observed for intrinsic biliary malignancy compared to extrinsic compressing tumours [22]. Several 
Figure I. Single operator cholangioscopy in a patient with an indeterminate hilar stricture

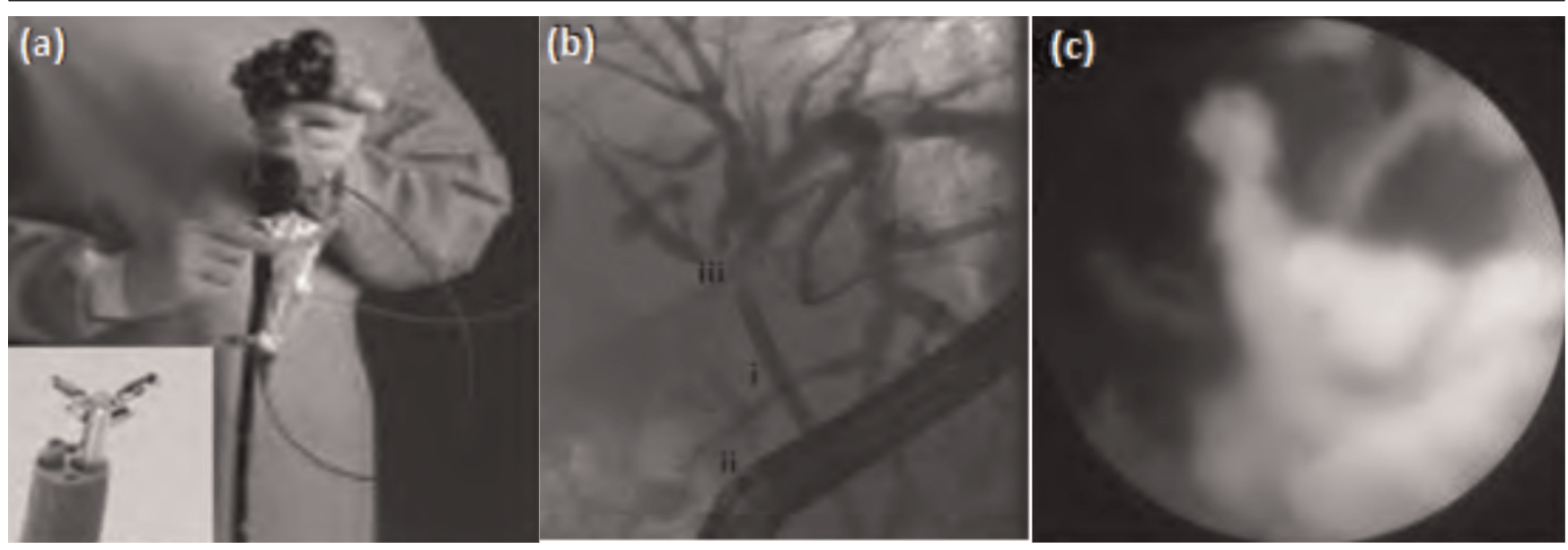

(a) Spyglass cholangioscope system (Boston Scientific Corp, Massachusetts, USA) with magnifed view of Spybite forceps. (b) Fluoroscopic view of hilar stricture at ERCP. (c) Cholangioscopic view of a hilar stricture with visualisation of the ulcerated, friable biliary mucosa.

ultra-slim endoscopes have also been developed. In comparison to single-operator cholangioscopy they are usually placed following standard ERCP, sphincterotomy and guidewire cannulation. Procedure times are therefore longer but compared with single-operator cholangioscopy they enable superior image quality, larger biopsy samples and chromendoscopy of the biliary mucosa [23].

\section{Novel optical techniques}

Chromendoscopy, autofluorescence and narrow-band imaging

Several techniques have been employed to augment the visualised mucosa during cholangioscopy. Methylene blue can successfully differentiate malignant lesions (staining them dark blue) [24] and ischemic strictures from normal mucosa [25]. Biliary narrow-band imaging enhances the vascular pattern of the mucosal surface and delineates tumour extent effectively [26,27]. Initial cholangioscopic studies with autofluorescence have been less promising; poor specificity and high rates of false positivity were observed [28].

\section{Elastic scattering spectroscopy}

Elastic scattering spectroscopy is a real time in vivo optical technique that detects changes in cells, via a probe that is passed through the working channel of an endoscope. It enables a field assessment for malignancy via an "optical biopsy", which has the potential to become an alternative to standard histology. A pilot study of elastic scattering spectroscopy from the distal duodenum, conducted by our group [29], gave a sensitivity of $86 \%$ and a specificity of $72 \%$ for the detection of pancreaticobiliary malignancy. These early results highlight its potential as a novel minimally invasive diagnostic test for pancreaticobiliary malignancy.

\section{Confocal laser endomicroscopy}

Confocal laser endomicroscopy (CLE) provides real-time histology during ERCP (Figure 2). A "cholangioflex" confocal probe (Mauna Kea Technologies, Paris, France) can be placed down a $1.2 \mathrm{~mm}$ working channel of a cholangioscope or the standard channel of a duodenoscope. Following an intravenous injection of fluorescein, a low-power laser directs light onto a single point on the biliary mucosa. Light emanating from this point is focused through a pinhole to a detector. This technique produces specific patterns that correlate with standard histology and differentiate between malignancy, inflammation and normal mucosa [30,31]. A recent multicentre study of 89 patients found CLE provided significantly higher diagnostic accuracy for malignant biliary strictures than standard ERCP (90\% vs. 73\%) [32]. Small studies have combined CLE with cholangioscopy and shown the diagnostic accuracy of the technique can be improved further (from $73 \%$ to $83 \%$ ) [32].

\section{Therapy}

Endoscopic biliary decompression in malignant obstruction The majority of patients diagnosed with pancreaticobiliary malignancy have unresectable disease. Receiving palliative chemotherapy is dependent on achieving adequate biliary drainage. Endoscopic biliary stenting to relieve obstruction has been associated with longer survival (19 vs. 16.5 months), fewer short-term complications and better cost-effectiveness than surgical decompression [33]. In most centres endoscopic management 
Figure 2. Confocal endomicroscopic image of normal biliary mucosa; identified by light grey background and reticular network of thin dark branching bands ( $<20$ microns). Image obtained with Cellvizio CholangioFlex ${ }^{\circledR}$ miniprobe. [Image courtesy of Mauna Kea Technologies, France]

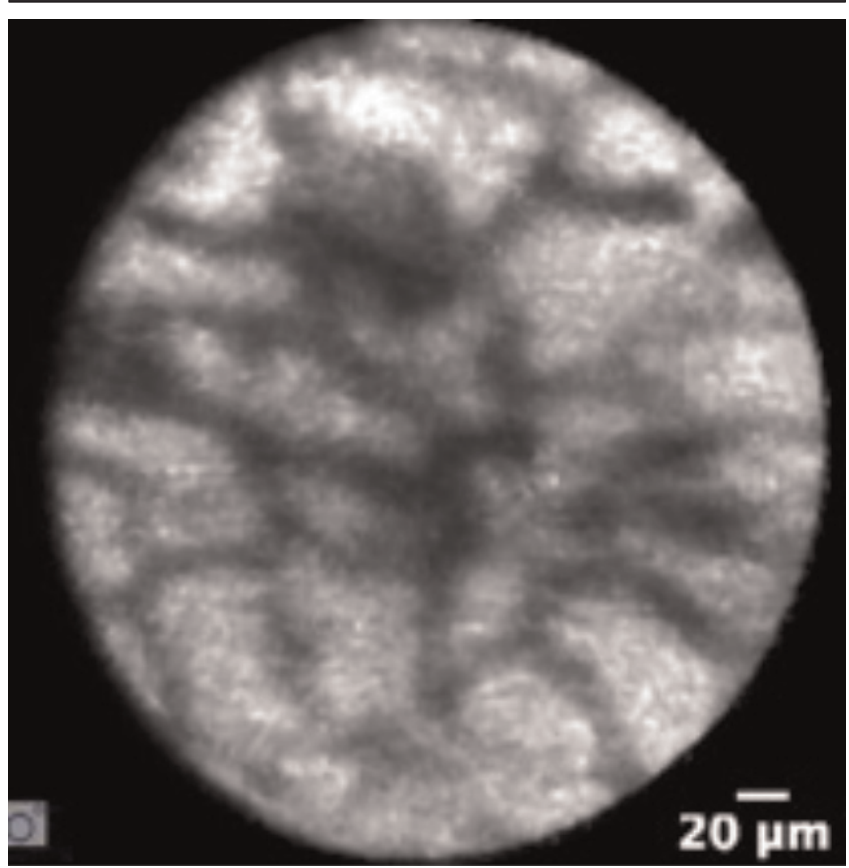

has therefore become the accepted initial approach in treating patients with malignant biliary obstruction.

\section{Cholangiocarcinoma}

Distal common bile duct obstruction

A meta-analysis of seven studies (1992-2006) compared plastic stents with self-expanding metal stents for malignant distal biliary obstruction [34] and found the relative risk (0.52) of recurrent biliary obstruction was significantly lower in the metal stent group. Since uncovered self-expanding metal stents are permanent, many patients are initially managed with a plastic stent while the confirmation of malignancy is awaited. However, the introduction of removable covered metal stents (WallFlex RX, Boston Scientific) has changed this practice.

Three randomised controlled trials have compared uncovered and covered self-expanding metal stent insertion in distal biliary obstruction. No significant differences in stent patency time, survival or complication rates were observed between covered and uncovered metal stents when used in the management of malignant distal biliary obstruction. However, covered stents did migrate significantly more often than uncovered stents, and tumor ingrowth occurred more frequently in uncovered stents [35-37].

Proximal biliary obstruction

Intrinsic or extrinsic compression of the biliary tree at the liver hilum can lead to disconnection of the right and left systems. In order for clinical jaundice to be relieved, it is estimated that at least one third of the liver has to be drained. Several studies have attempted to define the optimal stenting requirements in hilar obstruction and have found that $75-80 \%$ of patients will achieve decompression through a single stent but the remaining $20-25 \%$ will require two or more stents $[38,39]$. Bilateral stents can be placed side-by side or by a stent-in-stent technique. No discernible differences have been observed between the two methods [40]. Recently, a novel Y-shaped metal stent has been developed. In a preliminary study of 30 patients, $87 \%$ were successfully decompressed and stent occlusion occurred at a median of 176 days [41].

\section{Pancreatic Cancer}

Preoperative management of jaundiced patients with resectable pancreatic cancer remains controversial. A randomised controlled trial compared preoperative biliary drainage with surgery 4-6 weeks later to early surgery at 1 week. At 120 days after randomisation, 74\% of patients in the preoperative drainage group had suffered a serious complication, compared with $39 \%$ of patients in the early surgery group $(\mathrm{P}<0.001)$. Length of hospital stay and mortality did not vary between the groups [42]. However, in patients who are intensely symptomatic and those requiring neoadjuvant chemoradiotherapy, there may be a role for preoperative endoscopic biliary drainage, but a multidisciplinary team discussion is recommended in these complex cases [43]. In palliative lesions of the pancreas that are causing common bile duct obstruction and symptoms, a similar approach to the management of a distal cholangiocarcinoma is followed, typically with insertion of a self-expanding metal stent to enable longer-term palliation.

\section{Alternative biliary drainage options if access at ERCP fails Percutaneous transhepatic drainage (PTD)}

Endoscopic drainage, particularly of hilar strictures, can be challenging and PTD with stent placement provides an alternative method of biliary decompression. A retrospective study comparing percutaneous with endoscopic self-expanding metal stent insertion found rates of successful bilary drainage to be significantly higher in the percutaneous vs. the endoscopic group (93\% vs. $77 \%$ ). Rates of complications and survival were similar in the two groups [44]. 
Surgical bypass

Historically, biliary decompression has been achieved through surgical biliary bypass procedures. Although an effective technique, when compared to endoscopic drainage, surgery is associated with more short-term complications, increased mortality $(14 \%$ vs. $3 \%, \mathrm{P}=0.01)$ and longer recovery times (26 vs. 20 days in hospital, $\mathrm{P}<0.01$ ) [45].

\section{Endoscopic ultrasound-guided biliary drainage}

When endoscopic decompression is impossible due to failed cannulation, case series have shown that endoscopic ultrasound-guided biliary puncture from the duodenum or stomach is an effective alternative approach [46-49]. Passage of a guidewire through the tract enables standard cannulation and stent placement via a 'rendezvous' technique, or alternatively a stent can be placed across the tract to allow bile to drain directly into the duodenum or stomach.

\section{Novel endoscopic approaches to therapy}

A number of novel ablative and local therapies have been developed to treat cholangiocarcinoma. Ablative therapies such as photodynamic therapy or radiofrequency ablation can improve biliary drainage as individual treatments, in combination with biliary stenting, or unblock self-expanding metal stents in situ. Randomised studies comparing photodynamic therapy with biliary stenting to stenting alone have had conflicting results. Initial studies reported prolonged stent patency and improved survival after photodynamic therapy $[50,51]$. However, a subsequent UK phase III study closed early as overall survival was longer in those treated with stenting alone [52]. Radiofrequency ablation in combination with self-expanding metal stent placement has been reported in a small study of 22 patients, with a stent patency of $100 \%$ at 30 days [53]. Rarely, centres have used radiofrequency ablation alone to achieve biliary drainage but results of ongoing randomised controlled trials are awaited for validation of this technique [54]. Local therapies such as intraluminal brachytherapy can be applied to the tumour during ERCP. In two case series, median survival of patients with advanced hilar cholangiocarcinoma undergoing this technique was 11 and 14.5 months respectively $[55,56]$.

\section{Conclusion}

The re-emergence of peroral cholangioscopy, along with the development of several novel diagnostic techniques has led to improvements in the diagnostic accuracy of endoscopic assessment of indeterminate biliary strictures. Further evaluation of these new techniques through on-going trials will define their place in the algorithm of the diagnosis and management of pancreaticobiliary malignancy. Improvements in the range of biliary access techniques, endobilary stents and novel ablative treatments along with local therapies have led to significant improvements in the palliation of cholangiocarcinoma.

\section{Abbreviations}

CA, carbohydrate antigen; CLE, confocal laser endomicroscopy; ERCP, endoscopic retrograde cholangiopancreatography; EUS-FNA, endoscopic ultrasound - fine-needle aspiration; FISH, fluorescence in situ hybridisation; PTD, percutaneous transhepatic drainage.

\section{Disclosures}

The authors declare that they have no disclosures.

\section{Acknowledgements}

Steven Pereira is supported in part by NIH grant P01CA8420. The work was undertaken at UCLH/UCL who received a proportion of funding from the Department of Health's NIHR Biomedical Research Centres funding scheme. Margaret Keane was funded in part by a CRUK research bursary. NJM was a recipient of a Dr Falk Pharma UK/Core Research bursary for medical students.

\section{References}

I. Saluja SS, Sharma R, Pal S, Sahni P, Chattopadhyay TK: Differentiation between benign and malignant hilar obstructions using laboratory and radiological investigations: a prospective study. HPB (Oxford) 2007, 9:373-82.

2. Fernández-Esparrach $G$, Ginès $A$, Sánchez $M$, Pagés $M$, Pellisé $M$, Fernández-Cruz L, López-Boado MA, Quintó L, Navarro S, Sendino O, Cárdenas A, Ayuso C, Bordas JM, Llach J, Castells A: Comparison of endoscopic ultrasonography and magnetic resonance cholangiopancreatography in the diagnosis of pancreatobiliary diseases: a prospective study. Am J Gastroenterol 2007, 102:1632-9.

3. Sai JK, Suyama M, Kubokawa Y, Watanabe S, Maehara T: Early detection of extrahepatic bile-duct carcinomas in the nonicteric stage by using MRCP followed by EUS. Gastrointest Endosc 2009, 70:29-36.

4. Koea J, Holden A, Chau K, McCall J: Differential diagnosis of stenosing lesions at the hepatic hilus. World J Surg 2004, 28: 466-70.

5. Corvera CU, Blumgart LH, Darvishian F, Klimstra DS, DeMatteo R, Fong Y, D'Angelica M, Jarnagin WR: Clinical and pathologic features of proximal biliary strictures masquerading as hilar cholangiocarcinoma. J Am Coll Surg 2005, 201:862-9.

6. Kamisawa T, Okamoto A: Autoimmune pancreatitis: proposal of IgG4-related sclerosing disease. J Gastroenterol 2006, 41:6I3-25.

7. Chari ST, Smyrk TC, Levy MJ, Topazian MD, Takahashi N, Zhang L, Clain JE, Pearson RK, Petersen BT, Vege SS, Farnell MB: Diagnosis of autoimmune pancreatitis: the Mayo Clinic experience. Clin Gastroenterol Hepatol 2006, 4:1010-6 quiz 934.

8. Church NI, Pereira SP, Deheragoda MG, Sandanayake N, Amin Z, Lees WR, Gillams A, Rodriguez-Justo M, Novelli M, Seward EW, Hatfield ARW, Webster GJM: Autoimmune pancreatitis: clinical and radiological features and objective response to steroid therapy in a UK series. Am J Gastroenterol 2007, I 02:2417-25. 
9. Bellis M de, Sherman S, Fogel EL, Cramer H, Chappo J, McHenry L, Watkins JL, Lehman GA: Tissue sampling at ERCP in suspected malignant biliary strictures (Part 2). Gastrointest Endosc 2002, 56: 720-30.

10. Baron TH, Harewood GC, Rumalla A, Pochron NL, Stadheim LM, Gores G], Therneau TM, Groen PC de, Sebo TJ, Salomao DR, Kipp BR: A prospective comparison of digital image analysis and routine cytology for the identification of malignancy in biliary tract strictures. Clin Gastroenterol Hepatol 2004, 2:214-9.

11. Harewood GC, Baron TH, Stadheim LM, Kipp BR, Sebo T], Salomao DR: Prospective, blinded assessment of factors influencing the accuracy of biliary cytology interpretation. Am J Gastroenterol 2004, 99: 1464-9.

12. Moreno Luna LE, Kipp B, Halling KC, Sebo TJ, Kremers WK, Roberts LR, Barr Fritcher EG, Levy MJ, Gores GJ: Advanced cytologic techniques for the detection of malignant pancreatobiliary strictures. Gastroenterology 2006, I 3 I:1064-72.

\section{FlOOOPrime}

\section{RECOMMENDED}

13. Bergquist A, Tribukait B, Glaumann H, Broomé U: Can DNA cytometry be used for evaluation of malignancy and premalignancy in bile duct strictures in primary sclerosing cholangitis? J Hepatol 2000, 33:873-7.

14. Barr Fritcher EG, Voss JS, Jenkins SM, Lingineni RK, Clayton AC, Roberts LR, Halling KC, Talwalkar JA, Gores GJ, Kipp BR: Primary sclerosing cholangitis with equivocal cytology: Fluorescence in situ hybridization and serum CA 19-9 predict risk of malignancy. Cancer Cytopathol 2013 Jul 9, doi: 10.1002/cncy.21331. [Epub ahead of print]

15. Bangarulingam SY, Bjornsson E, Enders F, Barr Fritcher EG, Gores G, Halling KC, Lindor KD: Long-term outcomes of positive fluorescence in situ hybridization tests in primary sclerosing cholangitis. Hepatology 2010, 5 I: 174-80.

\section{FIOOOPrime}

16. Mohamadnejad M, DeWitt JM, Sherman S, LeBlanc JK, Pitt HA, House MG, Jones KJ, Fogel EL, McHenry L, Watkins JL, Cote GA, Lehman GA, Al-Haddad MA: Role of EUS for preoperative evaluation of cholangiocarcinoma: a large single-center experience. Gastrointest Endosc 20I I, 73:7I-8.

\section{FlOOOPrime \\ RECOMMENDED}

17. Gleeson FC, Rajan E, Levy MJ, Clain JE, Topazian MD, Harewood GC, Papachristou Gl, Takahashi N, Rosen CB, Gores G]: EUS-guided FNA of regional lymph nodes in patients with unresectable hilar cholangiocarcinoma. Gastrointest Endosc 2008, 67:438-43.

18. Gores GJ: Early detection and treatment of cholangiocarcinoma. Liver Transpl 2000, 6:S30-4.

19. Gartry DS, Falcon MG, Cox RW: Primary gelatinous drop-like keratopathy. $\mathrm{Br} J$ Ophthalmol 1989, 73:661-4.

20. Menzel J, Poremba C, Dietl KH, Domschke W: Preoperative diagnosis of bile duct strictures-comparison of intraductal ultrasonography with conventional endosonography. Scand J Gastroenterol 2000, 35:77-82.

\section{FlOOOPrime}

21. Tischendorf JJW, Krüger M, Trautwein C, Duckstein N, Schneider A, Manns MP, Meier PN: Cholangioscopic characterization of dominant bile duct stenoses in patients with primary sclerosing cholangitis. Endoscopy 2006, 38:665-9.

22. Chen YK, Parsi MA, Binmoeller KF, Hawes RH, Pleskow DK, Slivka A, Haluszka $O$, Petersen BT, Sherman S, Devière J, Meisner $S$, Stevens PD, Costamagna G, Ponchon T, Peetermans JA, Neuhaus H: Single-operator cholangioscopy in patients requiring evaluation of bile duct disease or therapy of biliary stones (with videos). Gastrointest Endosc 201 I, 74:805-14.
23. Larghi A, Waxman I: Endoscopic direct cholangioscopy by using an ultra-slim upper endoscope: a feasibility study. Gastrointest Endosc 2006, 63:853-7.

\section{FlOOOPrime}

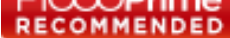

24. Hoffman A, Kiesslich R, Bittinger F, Galle PR, Neurath MF: Methylene blue-aided cholangioscopy in patients with biliary strictures: feasibility and outcome analysis. Endoscopy 2008, 40:563-7l.

25. Hoffman A, Kiesslich R, Moench C, Bittinger F, Otto G, Galle PR, Neurath MF: Methylene blue-aided cholangioscopy unravels the endoscopic features of ischemic-type biliary lesions after liver transplantation. Gastrointest Endosc 2007, 66:1052-8.

26. Itoi T, Sofuni A, Itokawa F, Tsuchiya T, Kurihara T, Ishii K, Tsuji S, Moriyasu F, Gotoda T: Peroral cholangioscopic diagnosis of biliary-tract diseases by using narrow-band imaging (with videos). Gastrointest Endosc 2007, 66:730-6.

27. Lu X, Itoi T, Kubota K: Cholangioscopy by using narrow-band imaging and transpapillary radiotherapy for mucin-producing bile duct tumor. Clin Gastroenterol Hepatol 2009, 7:e34-5.

28. Itoi T, Neuhaus $H$, Chen YK: Diagnostic value of imageenhanced video cholangiopancreatoscopy. Gastrointest Endosc Clin N Am 2009, 19:557-66.

29. Huggett MT BR, Sandanayake NS, Webster GJM, Bown SG, Lovat LB, Gilliams A, Pogue BW, Hasan T, Pereira SP: Photodynamic therapy of pancreatic cancer and elastic scattering spectroscopy of the duodenal mucosa for the detection of pancreaticobiliary malignancy. Proc SPIE7886, Optical Methods for Tumor Treatment and Detection: Mechanisms and Techniques in Photodynamic Therapy 2011; $X X, 78860$ J.

30. Meining A, Frimberger E, Becker V, Delius $\mathrm{S}$ von, Weyhern $\mathrm{CH}$ von, Schmid RM, Prinz C: Detection of cholangiocarcinoma in vivo using miniprobe-based confocal fluorescence microscopy. Clin Gastroenterol Hepatol 2008, 6:1057-60.

3I. Giovannini M, Bories E, Monges G, Pesenti C, Caillol F, Delpero JR: Results of a phase I-II study on intraductal confocal microscopy (IDCM) in patients with common bile duct (CBD) stenosis. Surg Endosc 20II, 25:2247-53.

32. Meining A, Chen YK, Pleskow D, Stevens P, Shah RJ, Chuttani R, Michalek J, Slivka A: Direct visualization of indeterminate pancreaticobiliary strictures with probe-based confocal laser endomicroscopy: a multicenter experience. Gastrointest Endosc 20II, 74:96I-8.

FlOOOPrime

33. Martin RCG, Vitale GC, Reed DN, Larson GM, Edwards MJ, McMasters KM: Cost comparison of endoscopic stenting vs surgical treatment for unresectable cholangiocarcinoma. Surg Endosc 2002, 16:667-70.

\section{FlOOOPrime} RECOMMENDED

34. Moss AC, Morris E, Leyden J, MacMathuna P: Malignant distal biliary obstruction: a systematic review and meta-analysis of endoscopic and surgical bypass results. Cancer Treat Rev 2007, 33:213-21.

\section{FIOOOPrime
RECOMMENDED}

35. Krokidis M, Fanelli F, Orgera G, Bezzi M, Passariello R, Hatzidakis A: Percutaneous treatment of malignant jaundice due to extrahepatic cholangiocarcinoma: covered Viabil stent versus uncovered Wallstents. Cardiovasc Intervent Radiol 2010, 33:97-106.

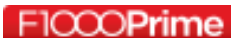

\section{FEOOPrime}

36. Isayama $\mathrm{H}$, Komatsu $\mathrm{Y}$, Tsujino $\mathrm{T}$, Sasahira N, Hirano K, Toda N, Nakai Y, Yamamoto N, Tada M, Yoshida H, Shiratori Y, Kawabe T, 
Omata M: A prospective randomised study of "covered" versus "uncovered" diamond stents for the management of distal malignant biliary obstruction. Gut 2004, 53:729-34.

\section{FlOOOPrime}

\section{RECOMMENDED}

37. Kullman E, Frozanpor F, Söderlund C, Linder S, Sandström P, LindhoffLarsson A, Toth E, Lindell G, Jonas E, Freedman J, Ljungman M, Rudberg C, Ohlin B, Zacharias R, Leijonmarck C, Teder K, Ringman A, Persson G, Gözen M, Eriksson O: Covered versus uncovered selfexpandable nitinol stents in the palliative treatment of malignant distal biliary obstruction: results from a randomized, multicenter study. Gastrointest Endosc 2010, 72:915-23.

\section{FIOOOPRime
RECOMMENDED}

38. Hintze RE, Abou-Rebyeh H, Adler A, Veltzke-Schlieker W, Felix R, Wiedenmann B: Magnetic resonance cholangiopancreatographyguided unilateral endoscopic stent placement for Klatskin tumors. Gastrointest Endosc 200I, 53:40-6.

39. Freeman ML, Overby C: Selective MRCP and CT-targeted drainage of malignant hilar biliary obstruction with selfexpanding metallic stents. Gastrointest Endosc 2003, 58:4I-9.

40. Kim KM, Lee KH, Chung YH, Shin JU, Lee JK, Lee KT, Shim SG: A comparison of bilateral stenting methods for malignant hilar biliary obstruction. Hepatogastroenterology 20I2, 59:34I-6.

4I. Hwang JC, Kim JH, Lim SG, Kim SS, Yoo BM, Cho SW: Y-shaped endoscopic bilateral metal stent placement for malignant hilar biliary obstruction: prospective long-term study. Scand J Gastroenterol 2011, 46:326-32.

\section{FlOOOPrime}

\section{RECOMMENDED}

42. van der Gaag NA, Rauws EAJ, van Eijck $\mathrm{CHJ}$, Bruno MJ, van der Harst E, Kubben FJGM, Gerritsen JJGM, Greve JW, Gerhards MF, Hingh IHJT de, Klinkenbijl JH, Nio CY, Castro SMM de, Busch ORC, van Gulik TM, Bossuyt PMM, Gouma DJ: Preoperative biliary drainage for cancer of the head of the pancreas. $N$ Engl J Med 2010, 362:129-37.

\section{FlOOOPRime
RECOMMENDED}

43. lacono C, Ruzzenente A, Campagnaro T, Bortolasi L, Valdegamberi A, Guglielmi A: Role of preoperative biliary drainage in jaundiced patients who are candidates for pancreatoduodenectomy or hepatic resection: highlights and drawbacks. Ann Surg 2013, 257:191-204.

\section{FlOOOPrime \\ RECOMMENDED}

44. Paik WH, Park YS, Hwang J, Lee SH, Yoon CJ, Kang S, Lee JK, Ryu JK, Kim Y, Yoon YB: Palliative treatment with self-expandable metallic stents in patients with advanced type III or IV hilar cholangiocarcinoma: a percutaneous versus endoscopic approach. Gastrointest Endosc 2009, 69:55-62.

\section{FlOOOPrime}

45. Smith AC, Dowsett JF, Russell RC, Hatfield AR, Cotton PB: Randomised trial of endoscopic stenting versus surgical bypass in malignant low bileduct obstruction. Lancet 1994, 344: 1655-60.

\section{FlOOOPrime}

\section{RECOMMENDED}

46. Giovannini M, Dotti M, Bories E, Moutardier V, Pesenti C, Danisi C, Delpero JR: Hepaticogastrostomy by echo-endoscopy as a palliative treatment in a patient with metastatic biliary obstruction. Endoscopy 2003, 35:1076-8.

\section{FlOOOPrime \\ RECOMMENDED}

47. Park DH, Song T, Eum J, Moon S, Lee SS, Seo D, Lee S, Kim M: EUSguided hepaticogastrostomy with a fully covered metal stent as the biliary diversion technique for an occluded biliary metal stent after a failed ERCP (with videos). Gastrointest EndosC 2010, 71:413-9.

\section{FlOOOPrime \\ RECOMMENDED}

48. Yamao K, Bhatia V, Mizuno N, Sawaki A, Shimizu Y, Irisawa A: Interventional endoscopic ultrasonography. J Gastroenterol Hepatol 2009, 24:509-19.

\section{FlOOOPrime \\ RECOMMENDED}

49. Siddiqui AA, Sreenarasimhaiah J, Lara LF, Harford W, Lee C, Eloubeidi MA: Endoscopic ultrasound-guided transduodenal placement of a fully covered metal stent for palliative biliary drainage in patients with malignant biliary obstruction. Surg Endosc 2011, 25:549-55.

\section{FlOOOPrime}

RECOMMENDED

50. Zoepf T, Jakobs R, Arnold JC, Apel D, Riemann JF: Palliation of nonresectable bile duct cancer: improved survival after photodynamic therapy. Am J Gastroenterol 2005, 100:2426-30.

5I. Gerhardt T, Rings D, Höblinger A, Heller J, Sauerbruch T, Schepke M: Combination of bilateral metal stenting and trans-stent photodynamic therapy for palliative treatment of hilar cholangiocarcinoma. Z Gastroenterol 2010, 48:28-32.

52. Pereira SP: Photodynamic therapy for pancreatic and biliary tract cancer: the United Kingdom experience. J Natl Compr Canc Netw 2012 Oct I, I0(Suppl 2):S48-5I.

53. Steel AW, Postgate AJ, Khorsandi S, Nicholls J, Jiao L, Vlavianos P, Habib N, Westaby D: Endoscopically applied radiofrequency ablation appears to be safe in the treatment of malignant biliary obstruction. Gastrointest Endosc 201 I, 73:149-53.

\section{FlOOOPrime}

RECOMMENDED

54. Shariff MIF, Khan SA, Westaby D: The palliation of cholangiocarcinoma. Curr Opin Support Palliat Care 2013, 7:168-74.

55. Kuvshinoff BW, Armstrong JG, Fong Y, Schupak K, Getradjman G, Heffernan N, Blumgart LH: Palliation of irresectable hilar cholangiocarcinoma with biliary drainage and radiotherapy. Br J Surg 1995, 82:1522-5.

56. Fletcher MS, Brinkley D, Dawson JL, Nunnerley H, Williams R: Treatment of hilar carcinoma by bile drainage combined with internal radiotherapy using 192iridium wire. $\mathrm{Br} J$ Surg 1983, 70:733-5.

57. Chalasani N, Baluyut A, Ismail A, Zaman A, Sood G, Ghalib R, McCashland TM, Reddy KR, Zervos X, Anbari MA, Hoen H: Cholangiocarcinoma in patients with primary sclerosing cholangitis: a multicenter case-control study. Hepatology 2000, $31: 7-11$.

58. Ramage JK, Donaghy A, Farrant JM, lorns R, Williams R: Serum tumor markers for the diagnosis of cholangiocarcinoma in primary sclerosing cholangitis. Gastroenterology 1995, 108:865-9.

59. Levy C, Lymp J, Angulo P, Gores GJ, Larusso N, Lindor KD: The value of serum CA $19-9$ in predicting cholangiocarcinomas in patients with primary sclerosing cholangitis. Dig Dis Sci 2005, 50:1734-40.

60. Leelawat K, Narong S, Wannaprasert J, Ratanashu-ek T: Prospective study of MMP7 serum levels in the diagnosis of cholangiocarcinoma. World J Gastroenterol 2010, 16:4697-703.

61. Li YG, Zhang N: Clinical significance of serum tumour M2-PK and CA19-9 detection in the diagnosis of cholangiocarcinoma. Dig Liver Dis 2009, 41:605-8. 
62. Liu L, Wang J, Liu B, Dai S, Wang X, Chen J, Huang L, Xiao X, He D: Serum levels of variants of transthyretin down-regulation in cholangiocarcinoma. J Cell Biochem 2008, 104:745-55.

\section{FlOOOPrime RECOMMENDED}

63. Qin X, Wang Z, Shi J, Lu M, Wang L, He Q: Utility of serum CA I9-9 in diagnosis of cholangiocarcinoma: in comparison with CEA. World J Gastroenterol 2004, 10:427-32.

64. Cheon YK, Cho YD, Moon JH, Jang JY, Kim YS, Kim YS, Lee MS, Lee JS, Shim CS: Diagnostic utility of interleukin-6 (IL-6) for primary bile duct cancer and changes in serum IL-6 levels following photodynamic therapy. Am J Gastroenterol 2007, 102:2164-70.

65. Silsirivanit A, Araki N, Wongkham C, Pairojkul C, Narimatsu Y, Kuwahara K, Narimatsu H, Wongkham S, Sakaguchi N: A novel serum carbohydrate marker on mucin 5AC: values for diagnostic and prognostic indicators for cholangiocarcinoma. Cancer 2011, I 1 7:3393-403.

66. Chapman MH, Sandanayake NS, Andreola F, Dhar DK, Webster G], Dooley JS, Pereira SP: Circulating CYFRA $2 \mathrm{I}-\mathrm{I}$ is a Specific Diagnostic and Prognostic Biomarker in Biliary Tract Cancer. J Clin Exp Hepatol 20I I, I:6-12.

67. Chen C, Shiesh S, Tsao H, Lin X: The assessment of biliary CA 125, CA 19-9 and CEA in diagnosing cholangiocarcinoma-the influence of sampling time and hepatolithiasis. Hepatogastroenterology 2002, 49:616-20.
68. Chen $\mathrm{C}$, Lin $\mathrm{X}$, Tsao H, Shiesh S: The value of biliary fibronectin for diagnosis of cholangiocarcinoma. Hepatogastroenterology 2003, 50:924-7.

69. Chen C, Tsai W, Wu H, Syu M, Wu C, Shiesh S: Diagnostic role of biliary pancreatic elastase for cholangiocarcinoma in patients with cholestasis. Clin Chim Acta 2008, 390:82-9.

70. Ayaru L, Stoeber K, Webster G], Hatfield ARW, Wollenschlaeger A, Okoturo O, Rashid M, Williams G, Pereira SP: Diagnosis of pancreaticobiliary malignancy by detection of minichromosome maintenance protein $\mathbf{5}$ in bile aspirates. Br J Cancer 2008, 98:1548-54.

7I. Koopmann J, Thuluvath PJ, Zahurak ML, Kristiansen TZ, Pandey A, Schulick R, Argani P, Hidalgo M, lacobelli S, Goggins M, Maitra A: Mac2-binding protein is a diagnostic marker for biliary tract carcinoma. Cancer 2004, 101:1609-15.

72. Shen J, Wang W, Wu J, Feng B, Chen W, Wang M, Tang J, Wang F, Cheng F, Pu L, Tang Q, Wang X, Li X: Comparative proteomic profiling of human bile reveals SSP4I I as a novel biomarker of cholangiocarcinoma. PLOS ONE 2012, 7:e47476.

73. Alvaro D, Macarri G, Mancino MG, Marzioni M, Bragazzi M, Onori P, Corradini SG, Invernizzi P, Franchitto A, Attili AF, Gaudio E, Benedetti A: Serum and biliary insulin-like growth factor I and vascular endothelial growth factor in determining the cause of obstructive cholestasis. Ann Intern Med 2007, I 47:45I-9.

74. Budzynska A, Nowakowska-Dulawa E, Marek T, Boldys H, Nowak A, Hartleb M: Differentiation of pancreatobiliary cancer from benign biliary strictures using neutrophil gelatinase-associated lipocalin. J Physiol Pharmacol 2013, 64:109-14. 